\title{
HIGH-RESOLUTION AGE MODEL BASED ON AMS RADIOCARBON AGES FOR KETTLE LAKE, NORTH DAKOTA, USA
}

\author{
Eric C Grimm \\ Illinois State Museum, Research and Collections Center, 1011 East Ash Street, Springfield, Illinois, USA. \\ Email: grimm@museum.state.il.us.
}

\begin{abstract}
A high-resolution age model was developed for Kettle Lake, North Dakota, USA, from a series of 53 accelerator mass spectrometry (AMS) radiocarbon ages calibrated with Bayesian statistical methods, which provide a monotonically increasing series of calibrated ages with depth. Evident in the sediment are several slumps, debris flows, or landslides, which are confirmed by ${ }^{14} \mathrm{C}$ dating. Removal of these facies produces a continuous sedimentary sequence for the past $13,000 \mathrm{yr}$ with exception of one $\sim 260$-yr hiatus associated with a 1.5-m-thick slump deposit. All ages except one are on terrestrial macrofossils and charcoal. A test age on aquatic organic detritus shows a hardwater effect of $600 \mathrm{yr}$ at $2000 \mathrm{cal} \mathrm{BP}$. Two ages from the same level on herbaceous charcoal and Chenopodium seeds are statistically the same, which further demonstrates the suitability of charcoal from grassland environments for AMS ${ }^{14} \mathrm{C}$ age control. However, 2 specimens of wood charcoal are too old relative to bracketing ages and glacial geologic history. These ages confirm the sedimentary interpretation of redeposition and provide a caution about the longevity of wood charcoal in the environment and its suitability for age control in lacustrine sediments.
\end{abstract}

\section{INTRODUCTION}

Studies of microfossils, charcoal, geochemistry, and stable isotopes from lakes in the northern Great Plains (NGP) of North America show that lake chemistry and vegetation are highly responsive to decadal- and century-scale climate change, particularly precipitation variations (Fritz et al. 1994, 2000; Laird et al. 1996a,b, 1998a,b; Valero-Garcés et al. 1997; Yu and Ito 1999; Clark et al. 2001, 2002; Grimm 2001; Yu et al. 2002; Umbanhowar 2004; Brown et al. 2005). In this sub-humid to semi-arid region, closed-basin lakes are particularly sensitive to moisture variations. Lake levels fluctuate in response to moisture variability, and salinity varies as lake volume and groundwater input change. Salinity may be a function of water volume (Laird et al. 1996a, 1998a; Valero-Garcés et al. 1997; Yu and Ito 1999; Yu et al. 2002), and carbonate precipitation may vary as a function of groundwater input of dissolved carbonate (Brown et al. 2005; Donovan and Grimm 2007). Changes in lake chemistry are recorded in diatom and ostracode assemblages and in sediment geochemistry. The prairie vegetation is highly responsive to periodic drought, and both pollen and charcoal reveal decadal-scale variations (Grimm 2001; Clark et al. 2002; Brown et al. 2005). Rapid rates of sediment deposition and minimal sediment mixing provide records with high temporal resolution. In deep NGP lakes that have never dried out, sediment thicknesses may exceed $20 \mathrm{~m}$ for complete lateglacial/Holocene sequences, which span the past 12,000-13,000 yr.

Although sediments from NGP lakes offer great potential for developing paleoenvironmental records with high temporal resolution, only a few decadal-scale records have been developed, and with 1 exception for only the late Holocene. These records include a diatom proxy for lake salinity for the past $2300 \mathrm{yr}$ from Moon Lake, North Dakota (Laird et al. 1996b, 1998a); a record of lake salinity from ostracode-shell $\mathrm{Mg} / \mathrm{Ca}$ ratios for the past $2100 \mathrm{yr}$ from Rice Lake, North Dakota (Yu and Ito 1999); and a multiproxy record of moisture variability from geochemistry, pollen, and charcoal for the past $4500 \mathrm{yr}$ from Kettle Lake, North Dakota (Brown et al. 2005). The only high-resolution mid-Holocene record is a diatom proxy for salinity from Oro Lake, Saskatchewan (Laird et al. 2007). Spectral analyses were carried out on the data from the 3 late Holocene sites, but chronological control on the first 2 of these sites was minimal, based on only 3 (Rice Lake) or 4 (Moon Lake) radiocarbon ages. Development of high-resolution records is hindered by the great time investment required to process hundreds or thousands of samples and by the expense for large numbers of ${ }^{14} \mathrm{C}$ ages necessary for high-resolution age models. Nevertheless, these studies have shown a great 
potential for extracting a high-resolution climate record for the entire Holocene in the NGP. Given the investment of time and money necessary to develop such a record, a lake was sought with the potential for as many climate proxies as possible. Existing studies have suggested that such a site would be a relatively small lake with a closed basin and simple morphometry without extensive shallow areas because of non-linear bathymetric effects on sedimentation and lake chemistry. The ideal lake should also have thick, laminated sediments, thereby making possible the development of a high-resolution record.

Kettle Lake, North Dakota, USA, met the criteria for a high-resolution multiproxy study of climate change. Coring indicated over $20 \mathrm{~m}$ of laminated postglacial sediment. A preliminary study of a $\sim 600$-yr sequence centered on $\sim 8000$ cal BP (Clark et al. 2002) indicated high sensitivity of geochemistry, pollen, and charcoal proxies to moisture variations. In addition to this paper, 2 other studies of these cores have been published. Donovan and Grimm (2007) reported the episodic appearance of the unusual guano mineral struvite in the middle Holocene section, which they hypothesize resulted from repeated visitations of large numbers of waterfowl when most other lakes in the region were dry. Brown et al. (2005) carried out spectral analysis on pollen, charcoal, and carbonate (as measured by loss-on-ignition) on the late-Holocene section (past $4500 \mathrm{yr}$ ), and they found a dominant 160-yr periodicity with a lower-frequency dampening of the signal. Analyses of mineralogy, charcoal, and pollen have now been completed for the entire core, spanning the past 13,000 yr. Mineralogy and charcoal analyses were conducted on contiguous 1-cm sections of core, for an average temporal resolution of $\sim 6 \mathrm{yr}$; and pollen analyses were carried out at $2-4 \mathrm{~cm}$ intervals, for $\sim 20$-yr resolution. High-resolution diatom studies have also been completed. Detailed analyses of these data will be reported elsewhere as will a detailed description of the sedimentology. This paper focuses on the development of an accurate age model to determine the timing of events and to facilitate spectral analyses.

Kettle Lake $\left(48^{\circ} 36^{\prime} 25^{\prime \prime} \mathrm{N}, 103^{\circ} 37^{\prime} 27^{\prime \prime} \mathrm{W}, 605 \mathrm{~m}\right.$ asl, 2.2 ha) is located in Williams County in northwestern North Dakota (Figure 1). As its name implies, the lake is a glacial kettle, lying in sandy to gravelly outwash. The lake has a simple morphometry and is $\sim 10 \mathrm{~m}$ deep. It lies in a deep depression, and the modern lake level is $\sim 10 \mathrm{~m}$ below the surrounding land surface. Additional site details are in Donovan and Grimm (2007).

\section{METHODS}

Two overlapping cores were collected from the center of Kettle Lake in July 1996 with a Wright square-rod piston corer, $5 \mathrm{~cm}$ in diameter (Wright et al. 1984). The cores were taken from a raft fixed in position by a rope stretched across the lake and by 2 large anchors set at right angles to the rope. The cores labeled A and B were spaced $\sim 1 \mathrm{~m}$ apart. Individual core drives were generally 1 -m long, and the 2 cores were offset vertically by $50 \mathrm{~cm}$. All depths reported are below the water surface. The mud-water interface was at $10.20 \mathrm{~m}$ depth, and the maximum core depth was $32.07 \mathrm{~m}$. Thus, the total core length was $21.87 \mathrm{~m}$. Most of the sediment is finely laminated aragonitic gyttja. The laminations may be annual (varves) in sections, but counts of laminations in the upper part of the core by 3 different people resulted in widely different numbers, and none corresponded with the age span estimated from ${ }^{14} \mathrm{C}$ dating. Both cores were split lengthwise to enable stratigraphic description. The splits were photographed in $15-\mathrm{cm}$ increments, and the photographs were then scanned at $600 \mathrm{dpi}$ and stitched together into single images for each core drive at a 1:1 scale. The laminations facilitated accurate stratigraphic correlation of the 2 cores, and a single composite core spanning the entire sedimentary sequence was constructed. The composite core consists of sections from both cores A and B. 


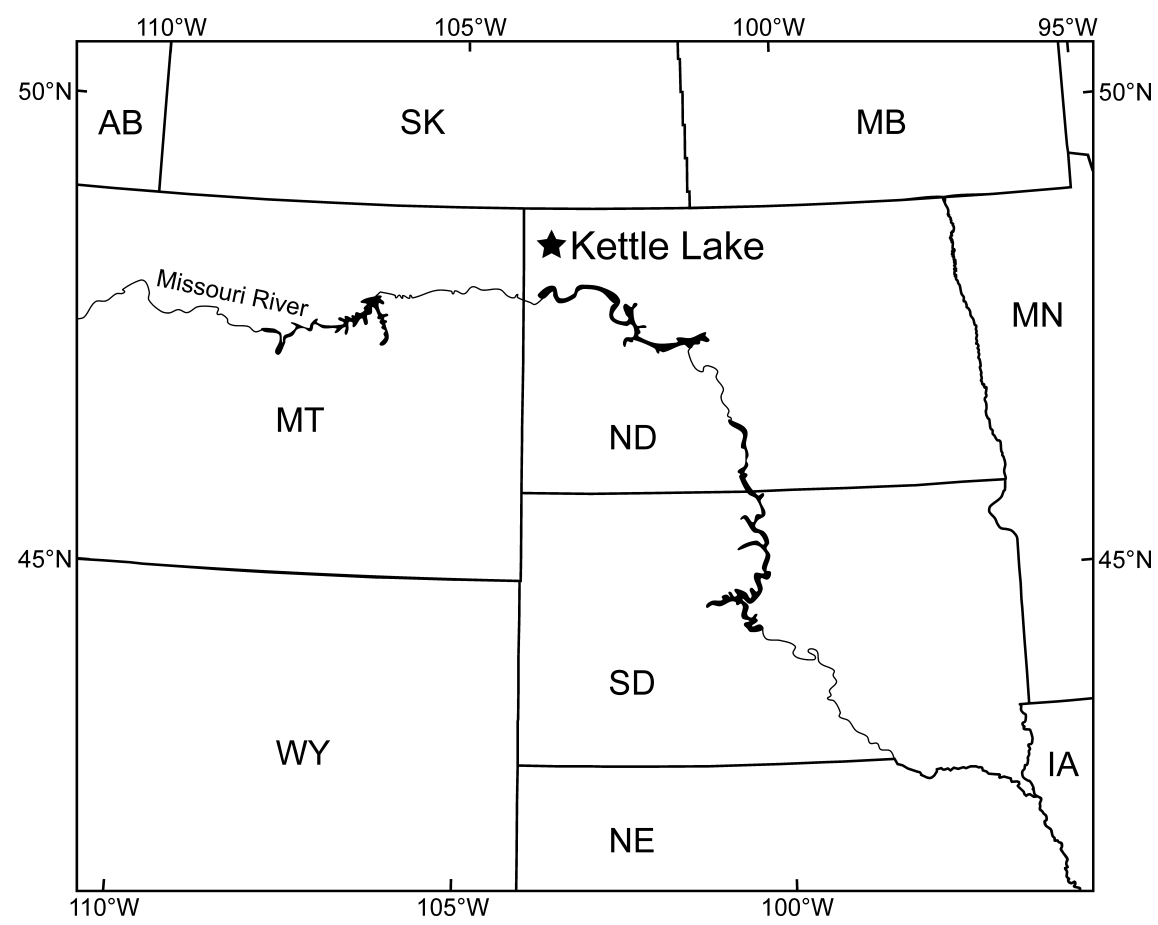

Figure 1 Location of Kettle Lake

The entire composite core was sliced into nominal 1-cm sections, which were stored in vials. The individual 1-cm slices were taken from either core A or B, but not both. The overlapping, unsliced core was retained as an archive. The thicknesses of the slices are "nominal" because an effort was made to maintain the actual thickness of the sediment. Overlapping cores showed complete recovery but with some compression, and thicknesses of sample slices were adjusted accordingly. For example, if a 1-m drive resulted in $90 \mathrm{~cm}$ of sediment with complete recovery indicated by the overlapping core, then the sample slices were $0.9 \mathrm{~cm}$ in thickness. To keep a record of the stratigraphic locations of core slices, the nominal $1-\mathrm{cm}$ slices were drawn on a hardcopy image of the core as the core was sliced. The digital images of the composite core were then sliced into nominal 4-cm sections, which were stretched to exactly $4 \mathrm{~cm}$ with imaging software. These stretched images were restitched into 1-m sections and printed at a 1:1 scale. Thus, measurements read off these images with a meter ruler correspond with the nominal sample depths.

Samples for all proxies - pollen, charcoal, diatoms, mineralogy — were taken from the labeled sample vials, thereby ensuring accurate stratigraphic correlation of the various proxies. Larger volumes of sediment to be sieved for materials for accelerator mass spectrometry (AMS) ${ }^{14} \mathrm{C}$ dating were sampled from the unsliced archive core. Stratigraphic correlation was made by visual comparison of the unsliced core with the images of the sliced core. Unique lamination sequences facilitated visual stratigraphic correlation.

For ${ }^{14} \mathrm{C}$ samples, $1-\mathrm{cm}$ slices from 1 split of the archive core were sieved for macrofossils and charcoal. If suitable materials but in an insufficient quantity were found in a sample, additional $1-\mathrm{cm}$ slices were added until an adequate quantity of material was recovered. Non-charcoalized terrestrial plant macrofossils were scarce throughout much of the core, and most of the samples for ${ }^{14} \mathrm{C}$ dating were charcoal. Initially, core sections targeted for dating were sieved until sufficient charcoal was 
obtained for an age determination. The 1-cm precision charcoal profile developed by Kendrick Brown (Brown et al. 2005) during this study proved invaluable for identifying charcoal peaks, which invariably produced large quantities of charcoal from the matching archive cores; as a consequence, ages obtained from charcoal peaks identified by Brown are from thinner core sections. Samples were first treated with $10 \% \mathrm{HCl}$, which disaggregated the carbonate-rich sediment and removed carbonate adhering to charcoal and macrofossils. Sediment was then gently screened through a stack of 0.42-, $0.2-$, and $0.15-\mathrm{mm}$ sieves. Charcoal and macrofossils were picked with forceps under a stereomicroscope. Picked samples were repicked at least twice to remove all sediment residues from the charcoal and macrofossil samples. Because the sediment contains lignite-although Kettle Lake had relatively little lignite compared to other northern Great Plains lakes - care was taken to distinguish charcoal from lignite. Under the stereomicroscope, charcoal is typically shiny black and shows cellular structure; whereas lignite, which appears black to the naked eye, is very dark brown and completely amorphous. If any doubt existed, the particle was discarded. Charcoal samples typically consisted of 10 to $>100$ fragments. Charcoal fragments were typically thin, linear-shaped, and $<2 \mathrm{~mm}$ in length, characteristic of burned grassland vegetation. Charcoal and macrofossil samples were stored in distilled water with a few drops of $10 \% \mathrm{HCl}$ to acidify and prevent fungal growth. The wet samples were submitted to the Center for Accelerator Mass Spectrometry (CAMS) at Lawrence Livermore National Laboratory. Because the fine herbaceous charcoal fragments tend to turn to dust if dried, it was easier for the ${ }^{14} \mathrm{C}$ laboratory to handle them wet. The disadvantage is that the samples could not be weighed, so determination of sufficient quantity $(\sim 1 \mathrm{mg})$ had to be made by eye.

${ }^{14} \mathrm{C}$ ages were calibrated to calendar years with the BCal calibration program (Buck et al. 1999; http: //bcal.sheffield.ac.uk), using the IntCal09 calibration curve (Reimer et al. 2009). BCal uses Bayesian statistics with an option for an a priori assumption that ages higher in the core are younger than ages lower in the core. When ages with overlapping calibrated probability distributions occur, $\mathrm{BCal}$ produces posterior probability distributions with non-overlapping modes, essentially wiggle-matching the ages to the calibration curve. Outlier analysis is an option within BCal. The calibrated ages from BCal were compared with calibrations from CALIB 6.0 (Stuiver and Reimer 1993) using the IntCal09 calibration curve, which makes no a priori assumptions constraining the calibration. CALIB was also used to calibrate ages that were not used for the age model. Although some of the rejected ${ }^{14} \mathrm{C}$ ages may be statistical outliers, most of these ages are probably analytically accurate but are on redeposited materials.

Outlier ${ }^{14} \mathrm{C}$ ages may be either too young or too old. Causes for ages being too young include laboratory contamination or material being dragged down alongside the core barrel. For ages that are too old, the most likely cause is redeposition of older material. Ages that $\mathrm{BCal}$ identified as outliers with $>95 \%$ probability would probably have been rejected as outliers by visual examination. The Bayesian assumption is that ages higher in the sequence should be younger. However, in contrast to tree rings, where outer rings must be younger than inner rings, plant macrofossils have potential taphonomic complications. The age of the macrofossil is not necessarily the age of deposition. Delicate or short-lived materials, such as herbaceous charcoal, seeds, and needles, are less likely to have an inbuilt age as, for example, wood or wood charcoal from long-lived trees may (Gavin 2001) and are less likely to have persisted long on the landscape before deposition in lake sediment. However, within-lake redepositional processes may move even delicate or short-lived materials. Large-scale redeposition events may be evident stratigraphically. However, small-scale redeposition events may not be so clearly visible or evident, especially for events that redeposit materials perhaps only a few decades or centuries old. Consequently, criteria more stringent than BCal were applied to the identification of outliers and stratigraphically reversed ${ }^{14} \mathrm{C}$ ages: reversed ages were not accepted if their $2-\sigma$ ranges as determined by CALIB did not overlap with stratigraphically adjacent ages. 


\section{RESULTS}

A large slump deposit $156 \mathrm{~cm}$ in thickness with sharply defined borders occurs from 2358 to 2514 $\mathrm{cm}$ (hereafter called the "big slump"). The slumped material does not have the fine laminations of sediment above and below, but rather consists of nearly massive, banded sediment. The bands are essentially horizontal and could be traced between the 2 cores, but were more variable than the fine laminations of the primary sediment. The nature of the slumped material and the abundance of littoral plant macrofossils (especially Schoenoplectus and Chenopodium seeds) suggest that this sediment was originally deposited in shallower water before slumping into the deeper portion of the basin. In addition to this slump, several strata originating from rapidly deposited debris flows or small landslides are evident. These strata consist of either poorly sorted layers of sand, which may have originated from the beach area or from the steep sides of the basin, or from sediments originally deposited in shallower water, which are characterized by laminations that are either contorted or lie at steep angles. The depths of these strata are $2560-2571 \mathrm{~cm}, 2657-2669 \mathrm{~cm}, 2686-2700 \mathrm{~cm}$, $2717-2780 \mathrm{~cm}, 2981-3010 \mathrm{~cm}, 3058-3081 \mathrm{~cm}, 3090-3106 \mathrm{~cm}$, and $3109-3125 \mathrm{~cm}$ (shown as gray bars in Figure 5). The sediment at the base of the core $(3157-3207 \mathrm{~cm})$ is sandy and was probably deposited very rapidly immediately after the lake formed. The bottom 4 layers listed above are sandy and may represent debris flows or landslides associated with repeated collapse of the basin margins as the underlying ice melted out.

A total of $53{ }^{14} \mathrm{C}$ ages were obtained from Kettle Lake (Table 1). Many of the AMS-dated samples are charcoal. Charcoal is necessarily of terrestrial origin, and most of the charcoal from Kettle Lake consists of fragile fragments derived from herbaceous prairie vegetation, which are unlikely to have resided long in the soils before being transported to the lake. Lake-sediment charcoal from herbaceous prairie plants has proven to provide reliable ages (Grimm et al. 2009). For instance, 2 ages from the same depth at Moon Lake, North Dakota, one on charcoal (5420 \pm 60 BP, CAMS-6823) and the other on an Ambrosia seed (5410 \pm 70 BP, CAMS-6824), differ by only 10 yr (Laird et al. 1996a). Two ages from overlapping levels in the Kettle Lake core also demonstrate the reliability of charcoal ages. An age on Chenopodium seeds (5950 \pm 35 BP, CAMS-105840) from a 1-cm section $(2258.5-2259.5 \mathrm{~cm})$ overlaps an age on charcoal $(5900 \pm 35 \mathrm{BP}$, CAMS-105839) from a $3-\mathrm{cm} \mathrm{sec}-$ tion $(2256.5-2259.5 \mathrm{~cm})$. As determined by CALIB 6.0, the ages overlap at the 1- $\sigma$ level. As determined by BCal, the $68 \%$ highest posterior density (HPD) ranges overlap slightly, and the $95 \%$ HPD ranges overlap substantially (Table 1). The slightly older age on seeds is consistent with their slightly greater depth.

Although all dated charcoal and macrofossil samples used for the Kettle Lake age model are of terrestrial origin, which eliminates the problem of hardwater error, a sample of unidentified organic detritus, presumably from aquatic macrophytes (CAMS-38086, $2680 \pm 100 \mathrm{BP}$ ), and a charcoal sample (CAMS-38087, $2080 \pm 50 \mathrm{BP}$ ) from the same level were dated to assess the magnitude of hardwater error. Not unexpectedly, the detritus is $600{ }^{14} \mathrm{C}$ yr older than the charcoal sample (Table 1). This magnitude of hardwater error at $\sim 2000$ cal BP is typical of Great Plains lakes (Grimm et al. 2009), and the detritus sample was rejected a priori for the age model. Two other ages from near the bottom of the sedimentary sequence were also rejected a priori, CAMS-113586 $(13,080 \pm 45 \mathrm{BP})$ and CAMS-113587 (29,230 $\pm 230 \mathrm{BP})$. These ages were on wood-charcoal samples from the sand layer at $2981-3010 \mathrm{~cm}$, and they clearly represent redeposited materials.

Five ages were obtained from the big slump. These ages, although out of sequence, are all in stratigraphic order within the slump, indicating that the slumped material is essentially an intact slab. The slump and these 5 ages were removed from the age model. The remaining $45{ }^{14} \mathrm{C}$ ages were cali- 
Table 1 AMS radiocarbon dates from Kettle Lake.

\begin{tabular}{|c|c|c|c|c|c|}
\hline $\begin{array}{l}\text { CAMS- } \\
n r^{\mathrm{a}}\end{array}$ & Depth $(\mathrm{cm})$ & ${ }^{14} \mathrm{C}$ age & $\begin{array}{l}\text { Median } \\
\text { age }\end{array}$ & $\begin{array}{l}\text { cal BP } \\
95 \% \text { range }^{b}\end{array}$ & Material \\
\hline 41153 & $1096-1098$ & $570 \pm 40$ & $598^{c}$ & $651-521$ & 2 Schoenoplectus seeds \\
\hline 105787 & $1119.5-1120.5$ & $125 \pm 40$ & $128^{\mathrm{c}}$ & $277--3$ & Charcoal \\
\hline 38080 & $1138-1144$ & $1380 \pm 90$ & $1295^{c}$ & $1512-1073$ & Charcoal \\
\hline 41154 & $1158-1164$ & $680 \pm 50$ & 603 & $681-550$ & Charcoal, Schoenoplectus seed \\
\hline 38081 & $1208-1212$ & $720 \pm 60$ & 680 & $744-570$ & Charcoal \\
\hline 38082 & $1243-1249$ & $870 \pm 60$ & 776 & $895-692$ & Charcoal \\
\hline 41155 & $1289-1295$ & $1250 \pm 50$ & $1188^{c}$ & $1282-1066$ & Charcoal, Schoenoplectus seed \\
\hline 32010 & $1316-1317$ & $960 \pm 50$ & 879 & $965-784$ & Charcoal \\
\hline 38083 & $1356-1360$ & $1240 \pm 70$ & 1166 & $1292-1001$ & Charcoal \\
\hline 38084 & $1393.7-1395.7$ & $1480 \pm 70$ & 1380 & $1525-1288$ & Charcoal, Typha seed \\
\hline 38085 & $1457-1458$ & $1770 \pm 50$ & 1685 & $1818-1563$ & Rosa seed \\
\hline 32009 & $1507-1512$ & $1960 \pm 70$ & 1906 & $2038-1742$ & $\begin{array}{l}\text { Charcoal, Schoenoplectus seed, } \\
\text { Chenopodium seed }\end{array}$ \\
\hline 38086 & $1540-1542$ & $2680 \pm 100$ & $2802^{\mathrm{c}}$ & $3065-2487$ & Organic detritus \\
\hline 38087 & $1540-1544$ & $2080 \pm 50$ & 2059 & $2295-1930$ & Charcoal \\
\hline 105837 & $1589.5-1590.5$ & $2320 \pm 40$ & 2340 & $2464-2160$ & Charcoal, Schoenoplectus seed \\
\hline 57143 & $1688-1690$ & $2580 \pm 40$ & 2565 & $2744-2463$ & Charcoal \\
\hline 57144 & $1724-1727$ & $2510 \pm 50$ & 2671 & $2751-2535$ & Charcoal \\
\hline 57145 & $1766-1770$ & $2880 \pm 50$ & 3015 & $3205-2870$ & Charcoal \\
\hline 105838 & $1870.5-1871.5$ & $3195 \pm 35$ & 3416 & $3479-3351$ & Charcoal \\
\hline 113569 & $1907.5-1908.5$ & $3425 \pm 35$ & 3666 & $3807-3575$ & Charcoal \\
\hline 113570 & $1931.5-1932.5$ & $3480 \pm 35$ & 3769 & $3848-3684$ & Charcoal \\
\hline 113571 & $2007.5-2008.5$ & $3820 \pm 35$ & 4213 & $4406-4092$ & Charcoal \\
\hline 105788 & $2058.5-2059.5$ & $4200 \pm 45$ & 4728 & $4851-4582$ & Charcoal \\
\hline 113572 & $2125.5-2126.5$ & $4765 \pm 35$ & 5513 & $5588-5332$ & Charcoal \\
\hline 113573 & $2151.5-2152.5$ & $4860 \pm 35$ & 5605 & $5660-5487$ & Charcoal \\
\hline 113574 & $2179.5-2180.5$ & $5305 \pm 35$ & 6085 & $6189-5950$ & Charcoal and Schoenoplectus seeds \\
\hline 105839 & $2256.5-2259.5$ & $5900 \pm 35$ & 6709 & $6786-6653$ & Charcoal \\
\hline 105840 & $2258.5-2259.5$ & $5950 \pm 35$ & 6786 & $6887-6713$ & Chenopodium seeds \\
\hline 113575 & $2273.5-2275.5$ & $5005 \pm 35$ & $5736^{\mathrm{c}}$ & $5891-5651$ & Charcoal \\
\hline 113576 & $2321.5-2322.5$ & $6275 \pm 40$ & 7207 & $7274-7027$ & Charcoal \\
\hline 116252 & $2349.5-2352.5$ & $6365 \pm 40$ & 7304 & $7419-7248$ & Charcoal \\
\hline 113577 & $2377.5-2378.5$ & $7490 \pm 35$ & $8323^{c}$ & $8383-8201$ & 15 Schoenoplectus seeds \\
\hline 116253 & $2417.5-2419.5$ & $7765 \pm 35$ & $8547^{c}$ & $8601-8449$ & Charcoal \\
\hline 105789 & $2424.5-2425.5$ & $7880 \pm 40$ & $8683^{c}$ & $8974-8585$ & Charcoal \\
\hline 113581 & $2458.5-2459.5$ & $8160 \pm 35$ & $9092^{\mathrm{c}}$ & $9252-9011$ & Charcoal \\
\hline 113582 & $2488.5-2489.5$ & $8785 \pm 35$ & $9801^{\mathrm{c}}$ & $10,115-9632$ & 10.5 Schoenoplectus seeds \\
\hline 116254 & $2514.5-2515.5$ & $6720 \pm 35$ & 7587 & $7662-7512$ & 2 Cenchrus longispinus seeds \\
\hline 116255 & $2538.5-2539.5$ & $6900 \pm 35$ & 7727 & $7822-7666$ & Charcoal \\
\hline 105841 & $2558.5-2559.5$ & $7035 \pm 40$ & 7870 & $7946-7789$ & Charcoal \\
\hline 57140 & $2581.8-2585.4$ & $7120 \pm 40$ & 7955 & $8016-7868$ & Charcoal \\
\hline 57141 & $2609.7-2613.5$ & $7410 \pm 50$ & 8251 & $8368-8058$ & $\begin{array}{l}\text { Charcoal, Poaceae seed, Cyper- } \\
\text { aceae seed }\end{array}$ \\
\hline 57142 & $2633.8-2638.0$ & $7770 \pm 50$ & 8546 & $8637-8422$ & Charcoal \\
\hline 105790 & $2715.5-2716.5$ & $8280 \pm 40$ & 9252 & $9391-9128$ & Charcoal \\
\hline 105791 & $2795.5-2796.5$ & $8305 \pm 40$ & 9361 & $9457-9249$ & Charcoal \\
\hline 113583 & $2830.5-2833.5$ & $8805 \pm 40$ & 9837 & $10,136-9679$ & Charcoal \\
\hline 113584 & $2915.5-2916.5$ & $9295 \pm 35$ & 10,498 & $10,586-10,301$ & Charcoal \\
\hline 113585 & $2934.5-2935.5$ & $9530 \pm 35$ & 10,844 & $11,076-10,699$ & Charcoal \\
\hline 105792 & $2961.5-2962.5$ & $9685 \pm 40$ & 11,138 & $11,217-10,870$ & Wood \\
\hline 113586 & $2990.5-2991.5$ & $13,080 \pm 45$ & $15,820^{\mathrm{c}}$ & $16,413-15,215$ & Charcoal \\
\hline 113587 & $3005.5-3007.5$ & $29,230 \pm 230$ & $33,910^{c}$ & $34,566-33,267$ & Charcoal \\
\hline 25277 & $3052.75-3053.25$ & $11,080 \pm 80$ & $12,966^{\mathrm{c}}$ & $13,142-12,710$ & Wood \\
\hline
\end{tabular}


Table 1 AMS radiocarbon dates from Kettle Lake. (Continued)

\begin{tabular}{llllll}
\hline $\begin{array}{l}\text { CAMS- } \\
\mathrm{nr}^{\mathrm{a}}\end{array}$ & Depth $(\mathrm{cm})$ & ${ }^{14} \mathrm{C}$ age & $\begin{array}{l}\text { Median } \\
\text { age }\end{array}$ & $\begin{array}{l}\text { cal BP } \\
95 \% \text { range }\end{array}$ & Material \\
\hline 105793 & $3053.5-3054.5$ & $10,720 \pm 45$ & 12,630 & $12,725-12,556$ & Wood \\
113588 & $3172.5-3176.5$ & $11,030 \pm 40$ & 12,874 & $13,071-12,705$ & Picea needles \\
\hline
\end{tabular}

${ }^{a}$ All dates from the Center for Accelerator Mass Spectrometry (CAMS), Lawrence Livermore National Laboratory.

${ }^{\mathrm{b}}$ The ranges are $95 \%$ highest posterior density regions for dates calibrated by $\mathrm{BCal}$ or the $2-\sigma$ ranges for dates calibrated with CALIB 6.0 (see text for references). Dates are calibrated with BCal unless otherwise indicated by note c.

${ }^{\mathrm{c}}$ Date calibrated with CALIB 6.0.

brated with BCal. A uniform probability of 80-60 cal BP was set for the top of the sequence. This age is just before the first appearance of Salsola pollen. Salsola is an introduced genus that reached North Dakota around AD 1890 (Dewey 1894).

Because ages with overlapping probability distribution functions influence each other in the calibration, $\mathrm{BCal}$ must then be rerun with the outliers removed. Run 1 identified 2 ages with a $100 \%$ outlier probability, which were eliminated (Table 2). Two samples immediately above CAMS-113575 (which had $100 \%$ outlier probability) had $99 \%$ outlier probabilities in Run 1. After the removal of CAMS-113575 in Run 2, the calibrated ages on these 2 samples had only $4 \%$ outlier probabilities. The third age from the top, CAMS-38080, had 100\% outlier probability in Run 1, and the 2 ages above this one had outlier probabilities of $99 \%$ and $52 \%$. Removal of CAMS-38080 did not improve the outlier status of these 2 ages, which still had outlier probabilities of $99 \%$ and $53 \%$. One of these ages was eliminated in Run 3 and the other in Run 4. Removal of either one reduces the outlier probability of the other to $3-4 \%$. However, retention of either of these ages in the age model produces a sharp kink in the age-depth relationship, whereas the sediment shows no evidence of irregular sedimentation. Elimination of the top 3 problematic ${ }^{14} \mathrm{C}$ ages in Run 5 produces a regular curve that extends from the Salsola rise to the fourth age determination and then through a long series of calibrated ages (Figures 3 and 5).

Three reversals occur in the uncalibrated ${ }^{14} \mathrm{C}$ chronology for which $\mathrm{BCal}$ does not identify an outlier at the $95 \%$ level (Figure 2). The ${ }^{14} \mathrm{C}$ age $1250 \pm 50$ (CAMS-41155) is older than the 2 ages below it; $\mathrm{BCal}$ determined a $35 \%$ outlier probability for this age and a $61 \%$ outlier probability for the age immediately below. However, the 2- $\sigma$ CALIB ranges of these 2 ages do not overlap. BCal forms prominent peaks in the calibrated probability density functions (pdfs) within small CALIB peaks that are outside the $2-\sigma$ ranges (Figure 2). Thus, CAMS-41155 was rejected as an outlier. The age $11,080 \pm 60$ (CAMS-25277) is older than the 2 ages below it; BCal determined only a $19 \%$ outlier probability for this age and a $15 \%$ probability for the age below it. However, because the $2-\sigma$ range of this age does not overlap the age below it and because it occurs within a section of the core with several stratigraphically identified redeposition events, it was rejected. The ages $2580 \pm 40$ (CAMS$57143)$ and $2510 \pm 50$ (CAMS-57144) are stratigraphically reversed, but their 2- $\sigma$ CALIB ranges overlap and are multimodal. BCal amplifies or reduces the probabilities within the overlapping CALIB modes such that the resultant pdf medians are no longer reversed (Figure 2).

If the probability distributions of 2 ages calibrated with no prior assumptions with CALIB do not overlap, then the HPD regions from $\mathrm{BCal}$ are essentially identical. However, when the probability distributions do overlap, the ages can constrain each other, and the BCal HPD regions differ from CALIB (Figures 3 and 4). Good examples are the following pairs of ages: $2580 \pm 40$ and $2510 \pm 50$ $\mathrm{BP}$ described above and $8280 \pm 40$ and $8305 \pm 40 \mathrm{BP}$ (Figures 3 and 4). The first of these pairs is reversed stratigraphically; however, BCal constrains the HPD regions to modes or portions of 
Table 2 BCal runs.

\begin{tabular}{|c|c|c|c|c|c|c|c|c|}
\hline $\begin{array}{l}\text { CAMS- } \\
\mathrm{nr}\end{array}$ & Depth $(\mathrm{cm})$ & $\begin{array}{l}{ }^{14} \mathrm{C} \text { age } \\
(\mathrm{BP})\end{array}$ & $\begin{array}{l}\text { Prior } \\
\text { outlier } \\
\text { prob }\end{array}$ & $\begin{array}{l}\text { Run } 1 \\
\text { post } \\
\text { outlier } \\
\text { prob }\end{array}$ & $\begin{array}{l}\text { Run } 2 \\
\text { post } \\
\text { outlier } \\
\text { prob }\end{array}$ & $\begin{array}{l}\text { Run } 3 \\
\text { post } \\
\text { outlier } \\
\text { prob }\end{array}$ & $\begin{array}{l}\text { Run } 4 \\
\text { post } \\
\text { outlier } \\
\text { prob }\end{array}$ & $\begin{array}{l}\text { Run } 5 \\
\text { post } \\
\text { outlier } \\
\text { prob }\end{array}$ \\
\hline 41153 & $1096-1098$ & $570 \pm 40$ & $5 \%$ & $99 \%$ & $99 \%$ & - & $4 \%$ & - \\
\hline 105787 & $1119.5-1120.5$ & $125 \pm 40$ & $5 \%$ & $52 \%$ & $53 \%$ & $3 \%$ & - & - \\
\hline 38080 & $1138-1144$ & $1380 \pm 90$ & $5 \%$ & $100 \%$ & - & - & - & - \\
\hline 41154 & $1158-1164$ & $680 \pm 50$ & $5 \%$ & $5 \%$ & $4 \%$ & $4 \%$ & $4 \%$ & $4 \%$ \\
\hline 38081 & $1208-1212$ & $720 \pm 60$ & $5 \%$ & $5 \%$ & $4 \%$ & $4 \%$ & $4 \%$ & $4 \%$ \\
\hline 38082 & $1243-1249$ & $870 \pm 60$ & $5 \%$ & $3 \%$ & $3 \%$ & $3 \%$ & $3 \%$ & $3 \%$ \\
\hline 41155 & $1289-1295$ & $1250 \pm 50$ & $5 \%$ & $35 \%$ & - & - & - & - \\
\hline 32010 & $1316-1317$ & $960 \pm 50$ & $5 \%$ & $61 \%$ & $4 \%$ & $4 \%$ & $4 \%$ & $4 \%$ \\
\hline 38083 & $1356-1360$ & $1240 \pm 70$ & $5 \%$ & $3 \%$ & $3 \%$ & $3 \%$ & $3 \%$ & $3 \%$ \\
\hline 38084 & $1393.7-1395.7$ & $1480 \pm 70$ & $5 \%$ & $4 \%$ & $4 \%$ & $4 \%$ & $4 \%$ & $4 \%$ \\
\hline 38085 & $1457-1458$ & $1770 \pm 50$ & $5 \%$ & $4 \%$ & $4 \%$ & $4 \%$ & $4 \%$ & $4 \%$ \\
\hline 32009 & $1507-1512$ & $1960 \pm 70$ & $5 \%$ & $0 \%$ & $0 \%$ & $0 \%$ & - & $0 \%$ \\
\hline 38087 & $1540-1544$ & $2080 \pm 50$ & $5 \%$ & $4 \%$ & $4 \%$ & $4 \%$ & $4 \%$ & $4 \%$ \\
\hline 105837 & $1589.5-1590.5$ & $2320 \pm 40$ & $5 \%$ & $11 \%$ & $11 \%$ & $11 \%$ & $11 \%$ & $11 \%$ \\
\hline 57143 & $1688-1690$ & $2580 \pm 40$ & $5 \%$ & $14 \%$ & $14 \%$ & $14 \%$ & $14 \%$ & $14 \%$ \\
\hline 57144 & $1724-1727$ & $2510 \pm 50$ & $5 \%$ & $4 \%$ & $4 \%$ & $3 \%$ & $3 \%$ & $3 \%$ \\
\hline 57145 & $1766-1770$ & $2880 \pm 50$ & $5 \%$ & $4 \%$ & $4 \%$ & $4 \%$ & $4 \%$ & $4 \%$ \\
\hline 105838 & $1870.5-1871.5$ & $3195 \pm 35$ & $5 \%$ & $5 \%$ & $5 \%$ & $5 \%$ & $5 \%$ & $5 \%$ \\
\hline 113569 & $1907.5-1908.5$ & $3425 \pm 35$ & $5 \%$ & $4 \%$ & $4 \%$ & $4 \%$ & $4 \%$ & $4 \%$ \\
\hline 113570 & $1931.5-1932.5$ & $3480 \pm 35$ & $5 \%$ & $3 \%$ & $3 \%$ & $3 \%$ & $3 \%$ & $3 \%$ \\
\hline 113571 & $2007.5-2008.5$ & $3820 \pm 35$ & $5 \%$ & $4 \%$ & $4 \%$ & $4 \%$ & $4 \%$ & $4 \%$ \\
\hline 105788 & $2058.5-2059.5$ & $4200 \pm 45$ & $5 \%$ & $5 \%$ & $5 \%$ & $5 \%$ & $5 \%$ & $4 \%$ \\
\hline 113572 & $2125.5-2126.5$ & $4765 \pm 35$ & $5 \%$ & $4 \%$ & $4 \%$ & $4 \%$ & $4 \%$ & $4 \%$ \\
\hline 113573 & $2151.5-2152.5$ & $4860 \pm 35$ & $5 \%$ & $7 \%$ & $7 \%$ & $7 \%$ & $7 \%$ & $7 \%$ \\
\hline 113574 & $2179.5-2180.5$ & $5305 \pm 35$ & $5 \%$ & $3 \%$ & $3 \%$ & $3 \%$ & $3 \%$ & $3 \%$ \\
\hline 105839 & $2256.5-2259.5$ & $5900 \pm 35$ & $5 \%$ & $99 \%$ & $4 \%$ & $4 \%$ & $4 \%$ & $4 \%$ \\
\hline 105840 & $2258.5-2259.5$ & $5950 \pm 35$ & $5 \%$ & $99 \%$ & $4 \%$ & $4 \%$ & $4 \%$ & $4 \%$ \\
\hline 113575 & $2273.5-2275.5$ & $5005 \pm 35$ & $5 \%$ & $100 \%$ & - & - & - & - \\
\hline 113576 & $2321.5-2322.5$ & $6275 \pm 40$ & $5 \%$ & $5 \%$ & $5 \%$ & $5 \%$ & $5 \%$ & $5 \%$ \\
\hline 116252 & $2349.5-2352.5$ & $6365 \pm 40$ & $5 \%$ & $4 \%$ & $4 \%$ & $4 \%$ & $4 \%$ & $4 \%$ \\
\hline 116254 & $2514.5-2515.5$ & $6720 \pm 35$ & $5 \%$ & $6 \%$ & $6 \%$ & $6 \%$ & $6 \%$ & $6 \%$ \\
\hline 116255 & $2538.5-2539.5$ & $6900 \pm 35$ & $5 \%$ & $4 \%$ & $4 \%$ & $4 \%$ & $4 \%$ & $4 \%$ \\
\hline 105841 & $2558.5-2559.5$ & $7035 \pm 40$ & $5 \%$ & $3 \%$ & $3 \%$ & $3 \%$ & $3 \%$ & $3 \%$ \\
\hline 57140 & $2581.8-2585.4$ & $7120 \pm 40$ & $5 \%$ & $5 \%$ & $5 \%$ & $5 \%$ & $5 \%$ & $5 \%$ \\
\hline 57141 & $2609.7-2613.5$ & $7410 \pm 50$ & $5 \%$ & $4 \%$ & $4 \%$ & $4 \%$ & $4 \%$ & $4 \%$ \\
\hline 57142 & $2633.8-2638.0$ & $7770 \pm 50$ & $5 \%$ & $5 \%$ & $5 \%$ & $5 \%$ & $5 \%$ & $5 \%$ \\
\hline 105790 & $2715.5-2716.5$ & $8280 \pm 40$ & $5 \%$ & $4 \%$ & $4 \%$ & $4 \%$ & $4 \%$ & $4 \%$ \\
\hline 105791 & $2795.5-2796.5$ & $8305 \pm 40$ & $5 \%$ & $3 \%$ & $3 \%$ & $3 \%$ & $3 \%$ & $3 \%$ \\
\hline 113583 & $2830.5-2833.5$ & $8805 \pm 40$ & $5 \%$ & $4 \%$ & $4 \%$ & $4 \%$ & $4 \%$ & $4 \%$ \\
\hline 113584 & $2915.5-2916.5$ & $9295 \pm 35$ & $5 \%$ & $5 \%$ & $5 \%$ & $5 \%$ & $5 \%$ & $5 \%$ \\
\hline 113585 & $2934.5-2935.5$ & $9530 \pm 35$ & $5 \%$ & $4 \%$ & $4 \%$ & $4 \%$ & $4 \%$ & $4 \%$ \\
\hline 105792 & $2961.5-2962.5$ & $9685 \pm 40$ & $5 \%$ & $4 \%$ & $5 \%$ & $5 \%$ & $5 \%$ & $5 \%$ \\
\hline 25277 & $3052.75-3053.25$ & $11,080 \pm 80$ & $5 \%$ & $19 \%$ & - & - & - & - \\
\hline 105793 & $3053.5-3054.5$ & $10,720 \pm 45$ & $5 \%$ & $15 \%$ & $5 \%$ & $5 \%$ & $5 \%$ & $5 \%$ \\
\hline 113588 & $3172.5-3176.5$ & $11,030 \pm 40$ & $5 \%$ & $4 \%$ & $4 \%$ & $4 \%$ & $4 \%$ & $4 \%$ \\
\hline
\end{tabular}

modes that do not overlap, and thereby produces a monotonically consistent sequence of calibrated ages. The second pair of ages is not reversed, but because their unconstrained pdfs overlap, BCal constrains the HPD regions to narrower ranges, and thereby improves the accuracy of the age model. 

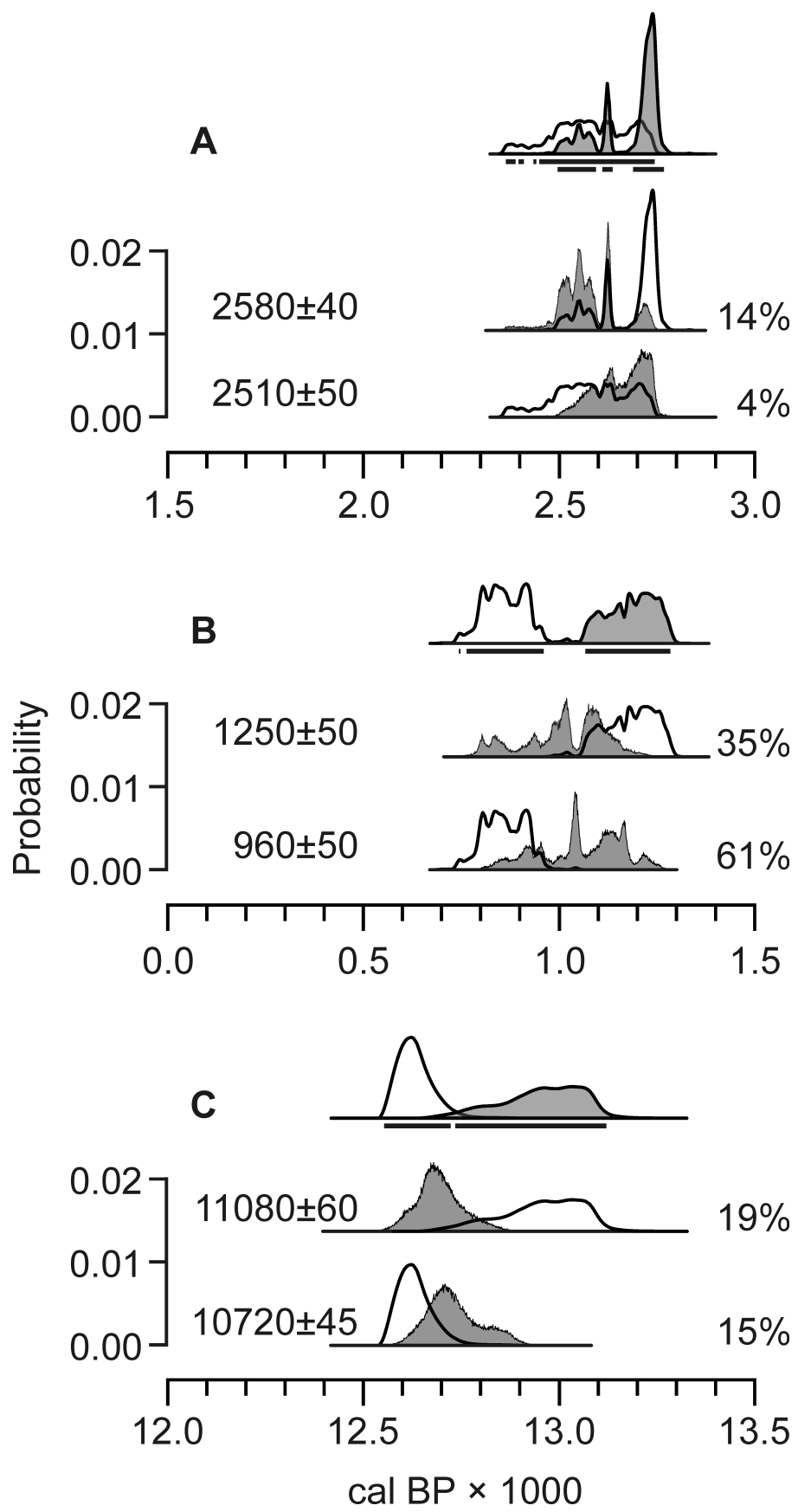

Figure 2 Stratigraphically reversed ${ }^{14} \mathrm{C}$ ages not identified as outliers with $\mathrm{BCal}$ at the $95 \%$ level. For each pair, the probability density functions (pdfs) of the 2- $\sigma$ calibrated ages determined with CALIB 6.0 are shown to the right of the letters (A, B, C). The $2-\sigma$ age ranges are indicated by the horizontal bars. In A, the $2-\sigma$ ranges substantially overlap, whereas in B and C they do not. Below the CALIB pdfs are shown the BCal pdf of each age (shaded) with the CALIB pdf (solid line). To the right of the $\mathrm{BCal}$ pdfs are the percent outlier probability as determined by $\mathrm{BCal}$. 

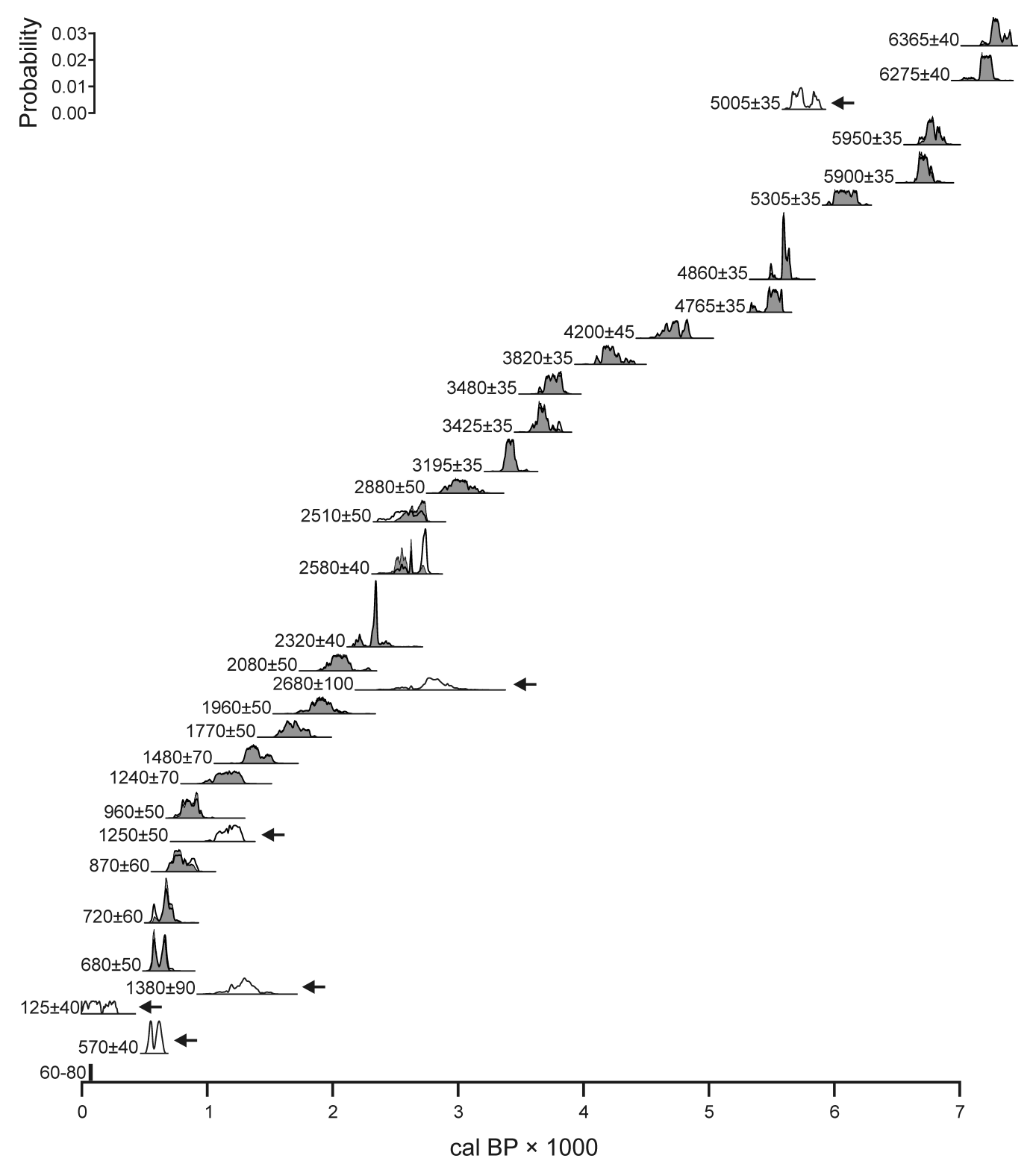

Figure 3 Probability density functions (pdfs) for the calibrated ${ }^{14} \mathrm{C}$ ages from Kettle Lake above the big slump. CALIB pdfs are shown as black lines; $\mathrm{BCal}$ pdfs are shaded. If the 2 pdfs are not congruent, $\mathrm{BCal}$ has adjusted the pdf based on the a priori assumption that ages higher in the sequence must be younger. If the CALIB pdfs for 2 adjacent ${ }^{14} \mathrm{C}$ ages do not overlap, the $\mathrm{BCal}$ pdfs are essentially identical. However, when the CALIB pdfs do overlap, the ages can constrain each other, and the BCal pdfs differ from CALIB. ${ }^{14} \mathrm{C}$ determinations shown with only a CALIB pdf (indicated by arrows) were rejected as outliers (see text).

BCal Run 5 on the final set of 39 accepted ${ }^{14} \mathrm{C}$ ages produced a series of calibrations with monotonically increasing median probabilities with depth (Table 1). An age model was developed from this series of calibrated ages by linear interpolation between the calibrated medians (Figure 5). With so 


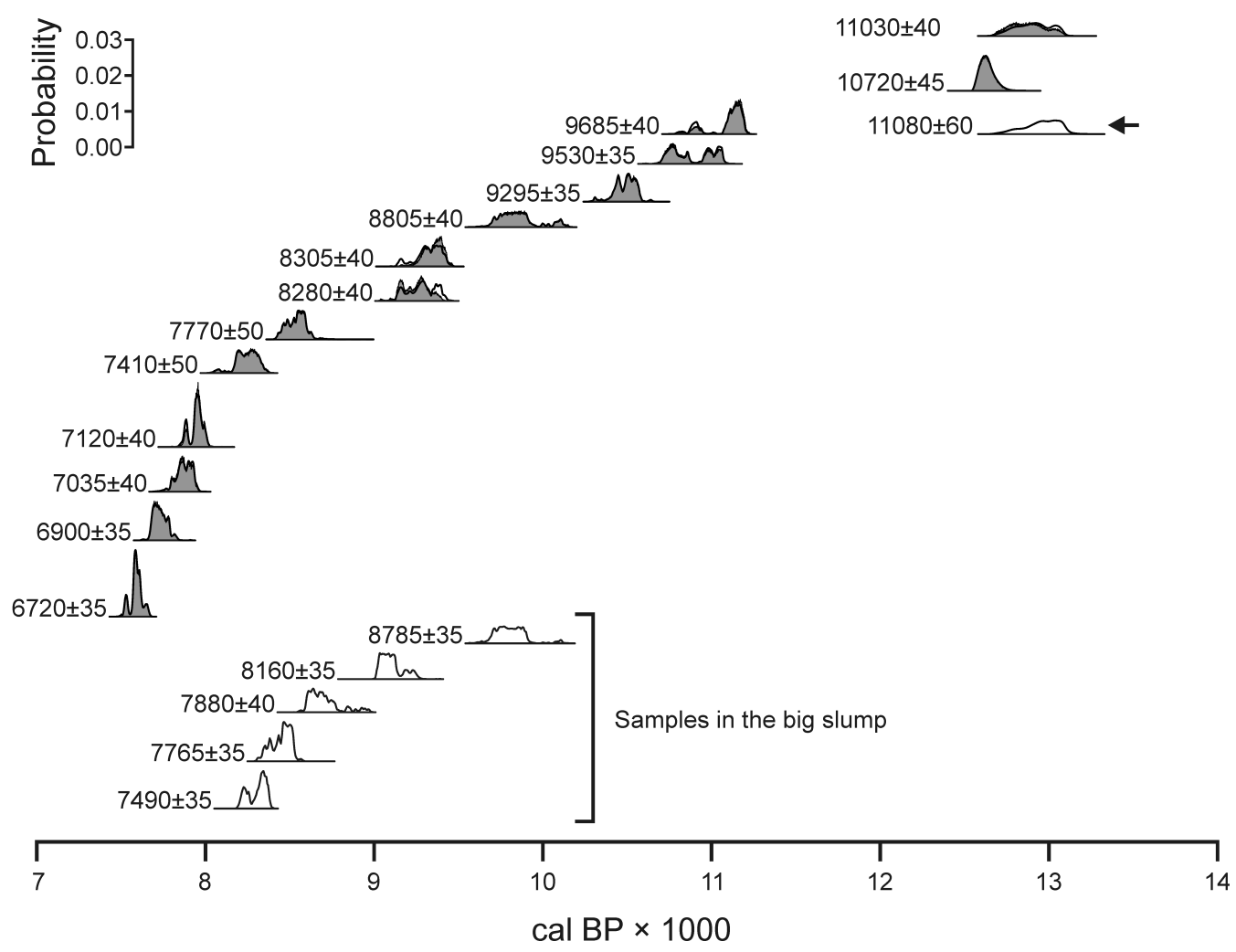

Figure 4 Probability density functions for the calibrated ${ }^{14} \mathrm{C}$ ages from Kettle Lake within and below the big slump. Because stratigraphic superposition could not be assumed a priori for samples in the slump, they were calibrated with CALIB only. For ${ }^{14} \mathrm{C}$ determinations below the slump, see the caption for Figure 3.

many age determinations, fitting a smoothed curve, such a spline, results in very little difference from the linear model in the interpolated ages. The slump sections were removed, and contiguous depths were assigned before developing the age model. ${ }^{14} \mathrm{C}$ ages within the big slump were calibrated with CALIB 6.0. Because these ages formed a consistent monotonic sequence, an age model was also developed for the slump section (Figure 5).

${ }^{14} \mathrm{C}$ ages closely bracket the big slump, and these ages are stratigraphically consistent with ages above and below. The age model indicates a gap of $263 \mathrm{yr}$ : 7587-7324 cal BP (Figure 5). The lower bracketing age of 7662-7512 cal BP (95\% HPD) at $2514.5-2515.5 \mathrm{~cm}$ is immediately below the slump. The upper bracketing age of 7419-7248 cal BP (95\% HPD) at $2349.5-2352.5 \mathrm{~cm}$ is $7 \mathrm{~cm}$ above the slump. According to the age model, the time interval between the upper bracketing age and the top of the slump is $20 \mathrm{yr}$, and the time interval between the 2 bracketing ages is $283 \mathrm{yr}$ (Figure 6). Thus, the estimate for the missing section of sediment is $\sim 260 \mathrm{yr}$. The sudden slumping of $1.5 \mathrm{~m}$ of sediment would have disturbed the watery, unconsolidated surficial sediments, and the appearance of a hiatus in the record is therefore not surprising. Based on the deposition time of sediment below the slump, the gap in the sedimentary sequence is estimated to be $\sim 43 \mathrm{~cm}$. The smaller debris flows lower in the core, several of which are well constrained by ${ }^{14} \mathrm{C}$ ages, including the largest of these at $2717-2780 \mathrm{~cm}$, do not appear to be associated with significant hiatuses in the record. 


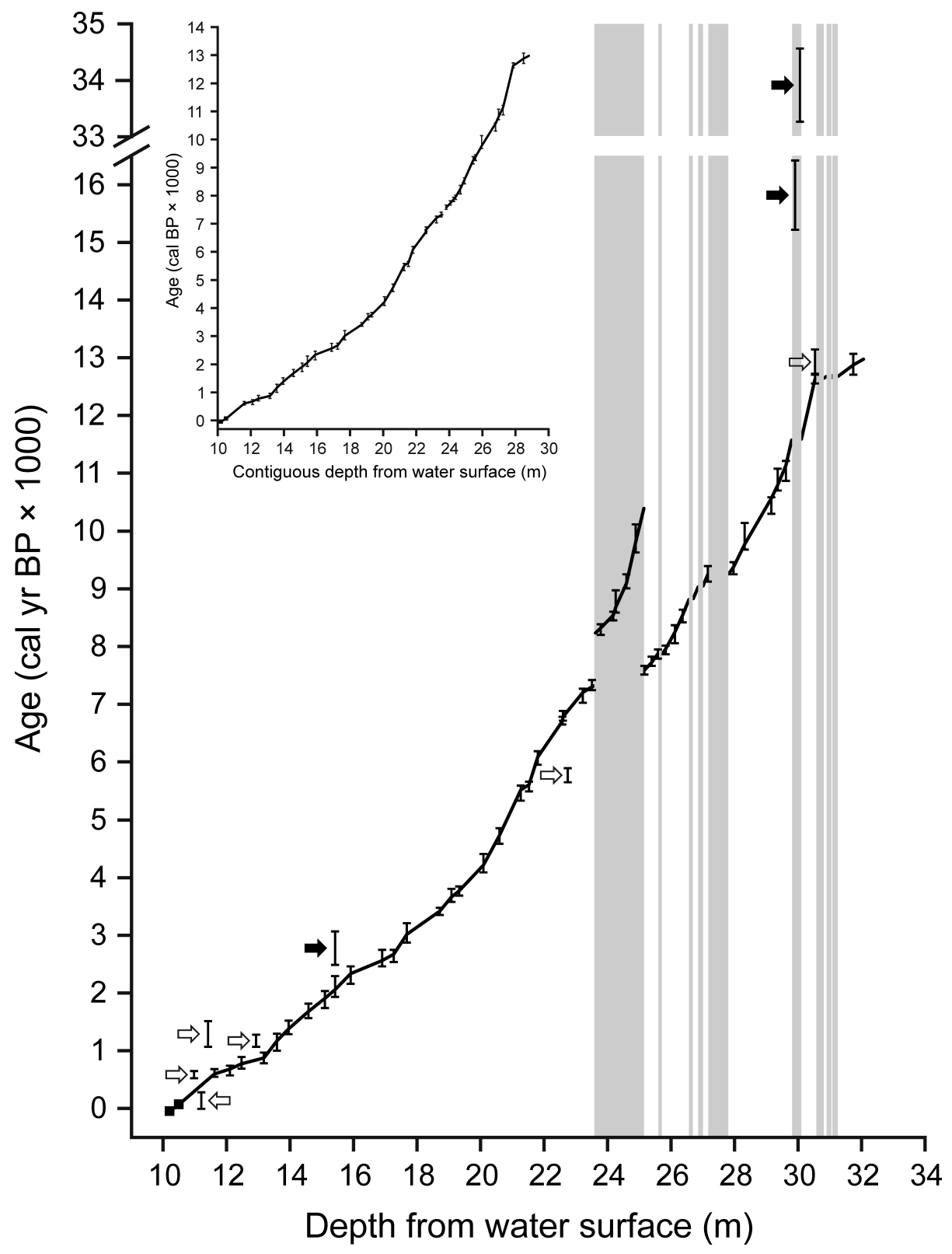

Figure 5 Age model for Kettle Lake. Calibrated ${ }^{14} \mathrm{C}$ ages are shown with $95 \%$ posterior probability densities (BCal) or 2- $\sigma$ ranges (CALIB 6.0). The age model is the black line connecting the median probabilities of the calibrated ages. Ages above and below the big slump were calibrated with BCal. Ages within the slump were calibrated with CALIB. Black arrows indicate ${ }^{14} \mathrm{C}$ determinations rejected a priori as outliers. Hollow arrows indicate ages rejected by the $\mathrm{BCal}$ outlier analysis or by non-overlapping $95 \%$ probability ranges as determined by CALIB. The ${ }^{14} \mathrm{C}$ ages rejected for the age model were calibrated with CALIB. In the inset, the slump, debris flow, or landslide deposits were removed before developing the age model. Estimated ages were not assigned to sediments within these smaller slumps. The black squares in the lower left corner are the fixed ages for the top of the core and the rise in Salsola pollen. 


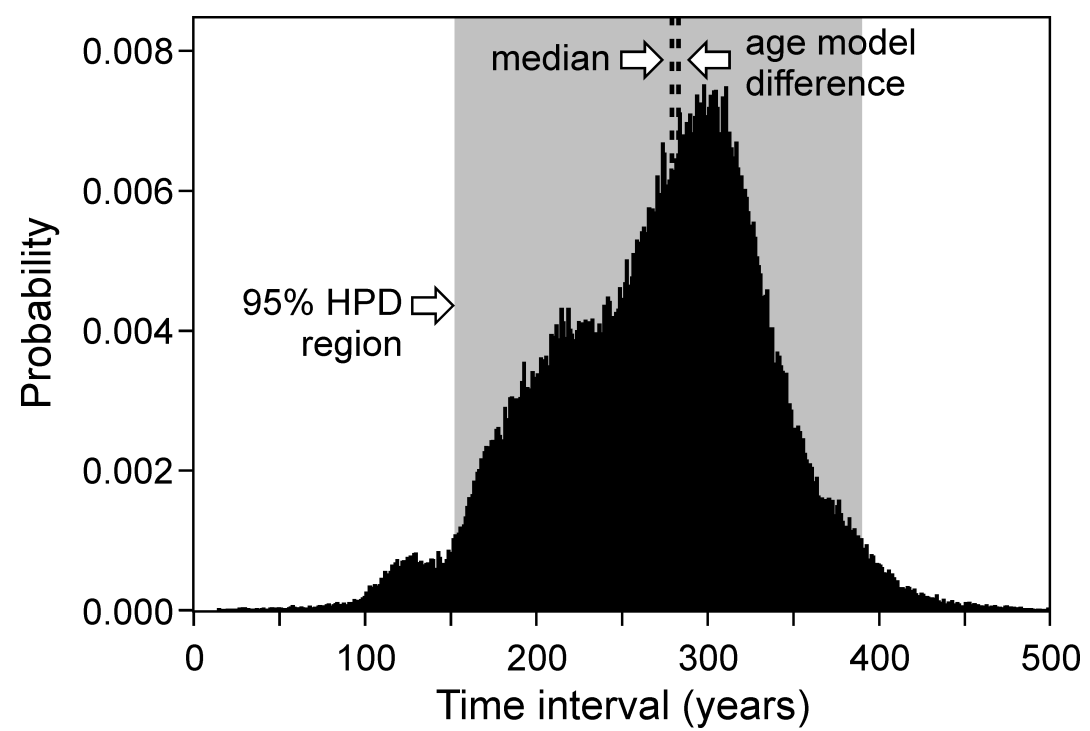

Figure 6 Posterior probability density function generated by $\mathrm{BCal}$ for the time elapsed between the $2{ }^{14} \mathrm{C}$ ages bracketing the big slump. The median probability is $279 \mathrm{yr}$. The age-model estimate for the difference between the 2 levels is $283 \mathrm{yr}$, which is the difference between the medians of the 2 calibrated ages.

\section{DISCUSSION}

The large number of calibrated ${ }^{14} \mathrm{C}$ ages from Kettle Lake forms the basis of a well-constrained age model. The observed deposition time $(\mathrm{yr} / \mathrm{cm})$, changes gradually with small variations, but is quite constant on a millennial timescale. An inflection point occurs at about 4500 cal BP, when deposition time decreases, either because of increased sedimentation or decreased compaction or both. Removal of slump deposits produces a complete, contiguous Holocene sequence, except for $\sim 43 \mathrm{~cm}$ and 260 yr at the big slump.

The laminated sediments of Kettle Lake along with the large number of ${ }^{14} \mathrm{C}$ ages greatly aid in the identification of slump, debris flow, or landslide deposits. A single age from the initial series of samples submitted to the AMS ${ }^{14} \mathrm{C}$ laboratory appeared to be a classic "reversed" date. Close inspection of the sediment, along with 4 additional ${ }^{14} \mathrm{C}$ ages, indicated that the reversed age was in a slump facies. These ages are analytically accurate but are on materials stratigraphically out of sequence.

The 2 ages in the sand layer at $2981-3010 \mathrm{~cm}$ are also reversed, but they are probably on redeposited materials and are also not statistical outliers. The older of these 2 ages $(29,230 \pm 230 \mathrm{BP}$, CAMS113587 ) is clearly too old based on regional glacial geology (Clayton and Moran 1982); however, the younger of these ages (13,080 $\pm 45 \mathrm{BP}$, CAMS-113586) is not implausibly old, and might have been accepted if not for other younger bracketing ages. In contrast to the delicate fragments of herbaceous charcoal dated from most of the core, these 2 ages were on chunky, woody charcoal. They reinforce conclusions from other studies that ages on wood charcoal are frequently too old (Barnekow et al. 1998; Gavin 2001; Oswald et al. 2005). Wood may be from a long-lived tree, and wood charcoal can persist for long periods on the landscape before ultimately being deposited in lake sediments. 
A common practice is to simply reject reversed or "too old" ages when developing age models for lacustrine sediments. However, these ages may not simply be statistical anomalies but instead may be an indication and warning of sedimentary discontinuities, which require further investigation. In the case of laminated sediments such as those from Kettle Lake, identification of slump facies is fairly straightforward. However, with massive nondescript sediments identification of slumps may be difficult, and additional ${ }^{14} \mathrm{C}$ ages may be necessary to resolve apparently anomalous out-ofsequence ages. Plant macrofossils and charcoal suitable for AMS ${ }^{14} \mathrm{C}$ dating may be redeposited. If redeposited, the critical question is whether only the dated specimens or the entire sediment package was redeposited. In the case of Kettle Lake, entire sedimentary units were redeposited, and therefore these have been removed to produce a continuous sequence.

Although most of the reported ${ }^{14} \mathrm{C}$ ages have comparatively narrow standard deviations (most are $\pm 35-70 \mathrm{yr}$ ), the $95 \%$ probability ranges of individual calibrated ages are on the order of 200-400 yr or greater. However, these confidence limits pertain to the absolute estimated age of any particular event. Given the evidence for regular sedimentation - after redeposited facies have been removedthe estimates of deposition time should be fairly accurate, permitting decadal-scale interpretations of cyclical or periodic phenomena, albeit not as accurately fixed in time.

\section{ACKNOWLEDGMENTS}

Joe Donovan initially recommended Kettle Lake as a site with great paleoenvironmental potential. I thank the coring team of George L Jacobson Jr, James S Clark, Wayne Lusardi, and Bryan Shuman. Pietra G Mueller sieved the sediments for macrofossils and charcoal and prepared specimens for AMS ${ }^{14} \mathrm{C}$ dating. The charcoal analyses of Kendrick Brown were invaluable for targeting narrow sections with sufficient materials for dating. I also thank John Southon for advice on sample preparation. I thank Maarten Blaauw, Andrés Christen, and Jack Williams for comments on an earlier version of this manuscript, and Steve Colman and an anonymous reviewer for comments on the submitted manuscript. This work was funded by the National Science Foundation under Grant ATM0213246 .

\section{REFERENCES}

Barnekow L, Possnert G, Sandgren P. 1998. AMS ${ }^{14} \mathrm{C}$ chronologies of Holocene lake sediments in the Abisko area, northern Sweden - a comparison between dated bulk sediment and macrofossil samples. GFF 120(1):59-67.

Brown KJ, Clark JS, Grimm EC, Donovan JJ, Mueller PG, Hansen BCS, Stefanova I. 2005. Fire cycles in North American interior grasslands and their relation to prairie drought. Proceedings of the National Academy of Sciences USA 102(25):8865-70.

Buck CE, Christen JA, James GN. 1999. BCal: an on-line Bayesian radiocarbon calibration tool. Internet $\mathrm{Ar}$ chaeology 7. http://intarch.ac.uk/journal/issue7/ buck_index.html.

Clark JS, Grimm EC, Lynch J, Mueller PG. 2001. Effects of Holocene climate change on the $\mathrm{C}_{4}$ grassland/ woodland boundary in the Northern Plains, USA. Ecology 82(3):620-36.

Clark JS, Grimm EC, Donovan JJ, Fritz SC, Engstrom DR, Almendinger JE. 2002. Drought cycles and landscape responses to past aridity on prairies of the northern Great Plains, USA. Ecology 83(3):595-601.
Clayton L, Moran SR. 1982. Chronology of late Wisconsinan glaciation in middle North America. Quaternary Science Reviews 1(1):55-82.

Dewey LH. 1894. The Russian thistle: its history as a weed in the United States, with an account of the means available for its eradication. Bulletin 15. United States Department of Agriculture, Washington, DC.

Donovan JJ, Grimm EC. 2007. Episodic struvite deposits in a northern Great Plains flyway lake: indicators of mid-Holocene drought? The Holocene 17(8):115569.

Fritz SC, Engstrom DR, Haskell BJ. 1994. 'Little Ice Age' aridity in the northern American Great Plains: a high-resolution reconstruction of salinity fluctuations from Devils Lake, North Dakota, USA. The Holocene 4(1):69-73.

Fritz SC, Ito E, Yu Z, Laird KR, Engstrom DR. 2000. Hydrologic variation in the northern Great Plains during the last two millennia. Quaternary Research 53(2): 175-84.

Gavin DG. 2001. Estimation of inbuilt age in radiocarbon 
ages of soil charcoal for fire history studies. Radiocarbon 43(1):27-44.

Grimm EC. 2001. Trends and palaeoecological problems in the vegetation and climate history of the northern Great Plains, U.S.A. Biology and Environment: Proceedings of the Royal Irish Academy 101B(1-2):4764.

Grimm EC, Maher Jr LJ, Nelson DM. 2009. The magnitude of error in conventional bulk-sediment radiocarbon dates from central North America. Quaternary Research 72(2):301-8.

Laird KR, Fritz SC, Grimm EC, Mueller PG. 1996a. Century-scale paleoclimatic reconstruction from Moon Lake, a closed-basin lake in the northern Great Plains. Limnology and Oceanography 41(5):890-902.

Laird KR, Fritz SC, Maasch KA, Cumming BF. 1996b. Greater drought intensity and frequency before $\mathrm{AD}$ 1200 in the northern Great Plains, USA. Nature 384(6609):552-4.

Laird KR, Fritz SC, Cumming BF. 1998a. A diatombased reconstruction of drought intensity, duration, and frequency from Moon Lake, North Dakota: a subdecadal scale record of the last 2300 years. Journal of Paleolimnology 19(2):161-79.

Laird KR, Fritz SC, Cumming BF, Grimm EC. 1998b. Early-Holocene limnological and climatic variability in the northern Great Plains. The Holocene 8(3):27585.

Laird KR, Michels A. Stuart CTL, Wilson SE, Last WM, Cumming BF. 2007. Examination of diatom-based changes from a climatically sensitive prairie lake (Saskatchewan, Canada) at different temporal perspectives. Quaternary Science Reviews 26(25-28): 3328-43.

Oswald WW, Anderson PM, Brown TA, Brubaker LB, Hu FS, Lozhkin AV, Tinner W, Kaltenrieder P. 2005.
Effects of sample mass and macrofossil type on radiocarbon dating of arctic and boreal lake sediments. The Holocene 15(5):758-67.

Reimer PJ, Baillie MGL, Bard E, Bayliss A, Beck JW, Blackwell PG, Bronk Ramsey C, Buck CE, Burr GS, Edwards RL, Friedrich M, Grootes PM, Guilderson TP, Hajdas I, Heaton TJ, Hogg AG, Hughen KA, Kaiser KF, Kromer B, McCormac FG, Manning SW, Reimer RW, Richards DA, Southon JR, Talamo S, Turney CSM, van der Plicht J, Weyhenmeyer CE. 2009. IntCal09 and Marine09 radiocarbon age calibration curves, $0-50,000$ years cal BP. Radiocarbon 51(4): $1111-50$.

Stuiver M, Reimer PJ. 1993. Extended ${ }^{14} \mathrm{C}$ data base and revised CALIB $3.0{ }^{14} \mathrm{C}$ age calibration program. $R a$ diocarbon 35(1):215-30.

Umbanhowar Jr CE. 2004. Interactions of climate and fire at two sites in the northern Great Plains, USA. Palaeogeography, Palaeoclimatology, Palaeoecology 208(1-2):141-52.

Valero-Garcés BL, Laird KR, Fritz SC, Kelts K, Ito E, Grimm EC. 1997. Holocene climate in the northern Great Plains inferred from sediment stratigraphy, stable isotopes, carbonate geochemistry, diatoms, and pollen at Moon Lake, North Dakota. Quaternary Research 48(3):359-69.

Wright Jr HE, Mann DH, Glaser PH. 1984. Piston corers for peat and lake sediments. Ecology 65(2):657-9.

Yu Z, Ito E. 1999. Possible solar forcing of century-scale drought frequency in the northern Great Plains. Geology 27(3):263-6.

Yu Z, Ito E, Engstrom DR, Fritz SC. 2002. A 2100-year trace-element and stable-isotope record at decadal resolution from Rice Lake in the northern Great Plains, USA. The Holocene 12(5):605-17. 